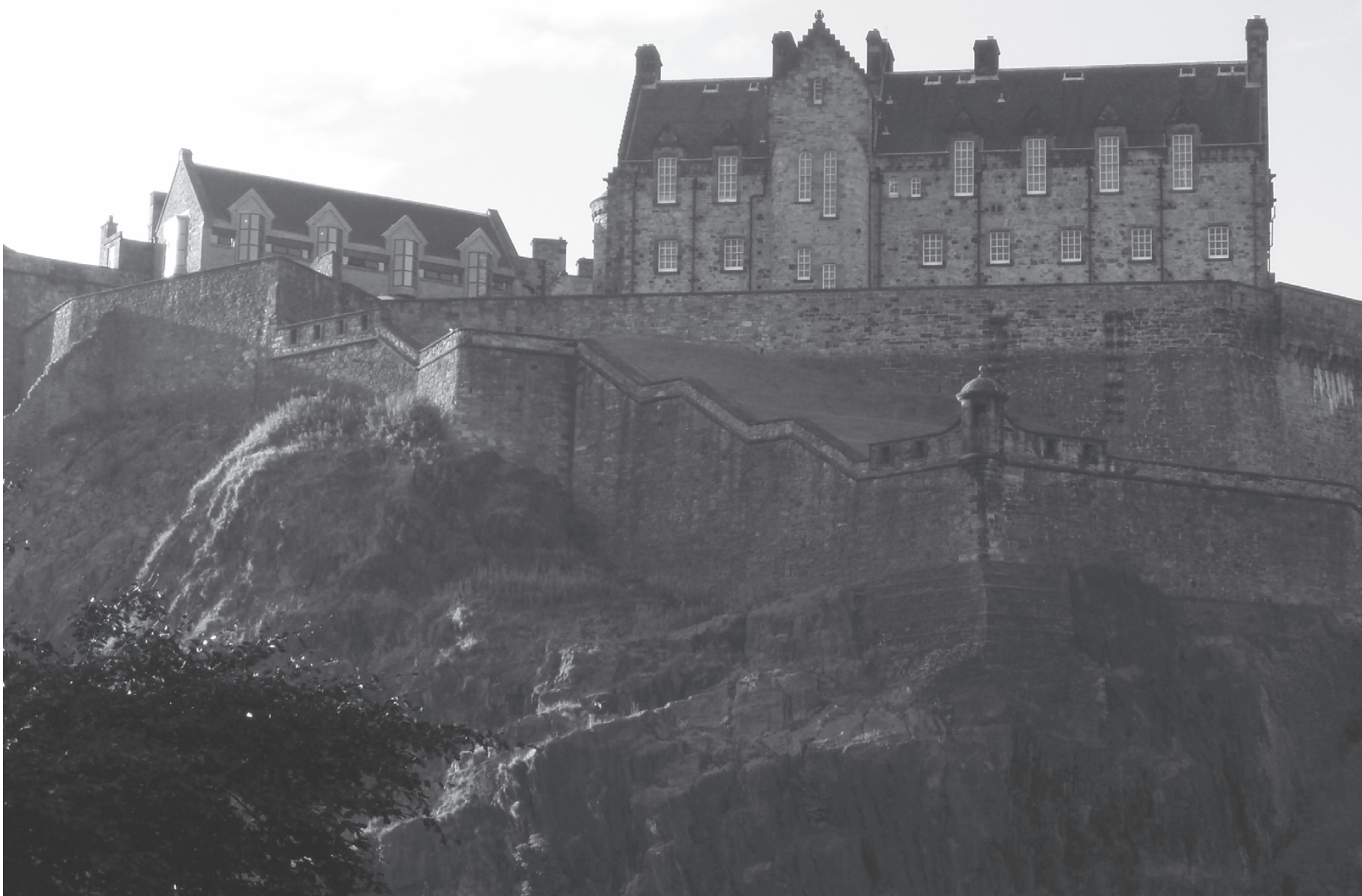

Ecos de Economía $\mid$ №. 30 | Medellín, abril de 2010 | pp. 99-120

Early Neoclassical views on Monopoly: the Cournotian heritage 


\section{Andrés Álvarez}

\section{Resumen}

A pesar de la influencia teórica indiscutible de Cournot sobre la teoría contemporánea, su legado en relación con las políticas económicas y en particular con la regulación de los monopolios es mucho menor. Este trabajo explora las formas diversas que tiene el análisis de las estructuras monopólicas de mercado propuesto por Cournot, partiendo de su modelo teórico hasta su análisis más normativo y empírico. Utilizando textos poco conocidos del autor se pone en evidencia la versatilidad de sus ideas y la riqueza de su legado analitico. A partir de estos elementos se intenta reconstruir la influencia que sus ideas tuvieron sobre tres de los principales autores de finales del siglo XIX: Walras, Edgeworth y Marshall. Se muestra que existe una representación teórica que constituye la referencia indiscutible sobre los monopolios pero que se enriquece en los análisis normativos y resulta en propuestas de regulación y de política económica diversas que cada uno de estos autores desarrolla y se apropia de manera diferente.

Palabras clave: Cournot, Walras, Edgeworth, Marshall, Monopolio, Organización Industrial

\section{Abstract}

In spite of Cournot's unquestionable influence on contemporary theory, his legacy regarding economic policy and, especially, the regulation of monopolies is mostly unknown. In this paper I explore the several forms of Cournot's analysis of monopolistic market structures, starting with his theoretical model up to his normative and empirical examination. With the help of little known texts of the author I aim at showing the versatility of his ideas and the richness of his analytical legacy. Against this setup I retrace his influence over three of the most important economists of the end of the XIXth century: Walras, Edgeworth and Marshall. I show that there exists a theoretical representation that constitutes the indisputable reference regarding monopolies that is enriched with normative analyses and leads each one of them to their own specific proposals in regulation and economic policy.

Keywords: Cournot, Walras, Edgeworth, Marshall, Monopoly, Industrial Organization

\section{Clasificación JEL:}




\title{
Early Neoclassical views on Monopoly: the Cournotian heritage
}

\author{
Andrés Álvarez*
}

\section{Introduction}

This paper analyses how Cournot's views on Monopoly have influenced the early neoclassical authors. It is argued that there are two different points of view derived from the cournotian evaluation of the consequence of Monopoly. The first one is a purely theoretical construction that has been adopted by modern economic theory. Even if it is a theoretical one it has normative consequence. From this point of view, Cournot and his heirs have derived normative elements justifying a negative appreciation on Monopoly. The second is a more pragmatic point of view. Whereas the former is purely theoretical the latter is derived from multiple examples and it cannot be based on the same theoretical framework as the well known theory of monopoly prices. From this pragmatic point of view, Cournot constructs a more positive appreciation on the existence of monopolies.

These two different appraisals on imperfect markets have influenced in different ways the works of the authors of the Marginal Revolution. Following this distinction we study the different points of view of Walras, Edgeworth and Marshall on Monopoly. We show that even if Walras's

Fecha de recepción: agosto 15 de 2009 - Fecha de aceptación: enero 29 de 2010.

* Profesor Asociado, Escuela de Economía Universidad Nacional de Colombia. Grupo de investigación en pensamiento y teoría económica GIPTE. Contact: caalvarezga@unal.edu.co. The author thanks the participants on the 13th Annual Meeting of the European Society for the History of Economic Thought and in particular Manuela Mosca for her very accurate and helpful comments on a previous version of this paper. This version has benefited a lot from comments of participants at the first Jornadas Colombianas de Historia del Pensamiento organized in Medellín by the EAFIT and the University of Antioquia, November 2009. In particular: remarks, criticisms and encouragements received from Francesco Bogliacino were very useful to improve this paper. All errors, confusions and other problems remain my sole responsibility. 


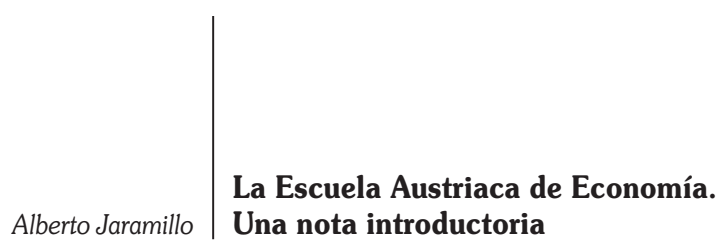

theory of Monopoly does not have the same theoretical foundations of Cournot's, his normative point of view on monopolies is closely related with the "purely theoretical" conclusions. Walras frequently quoted Cournot on these matters. Edgeworth and Marshall have a different point of view on Monopoly, mainly pragmatic and sometimes quite positive from the normative point of view. However Walras's as well as Edgeworth's and Marshall's theories on monopoly unveil the distance between their pure economic theories on perfect competition and their ideas on imperfect competition. Even if they tried both seriously to found their analysis of imperfect competition market structures as deviations from their theoretical representations of a perfectly competitive market, the resulting analyses do not satisfied their methodological desiderata. We conclude that the marginalists' views on imperfect competition are not always constructed as "perturbations" or "frictions" of a perfectly competitive market. Imperfect competition and in particular monopolies push them to consider some modifications of their theoretical frameworks or even to introduce more pragmatic considerations leading them to conclusions rather doctrinal than theoretical.

As Cournot's theory of Monopoly has an important place in modern Economics, most historians of economics has focused his attention on his methodological legacy as the precursor of mathematical economics. The purely theoretical point of view seems the sole aspect of Cournot's monopoly theory remaining in history of economic thought. Two recent papers try to avoid this common view on Cournot. Friedman (2000) presents the successive historical stages of this legacy. He concludes that the cournotian influence on Walras, Edgeworth and Marshall relies on the theory of oligopoly and the famous Bertrand-Cournot debate. Monopoly theory is not mentioned as a central issue. Dos Santos Ferreira (2004) focuses his attention on a more general conception of competition, including Monopoly, Oligopoly and Perfect Competition. However, this author focuses his attention on the cooperative vs. non-cooperative aspects of these analyses. We agree in the general views of Dos Santos Ferreira's paper, but we propose an original lecture of the analysis on normative views of the authors on Monopoly. Our analysis enriched the literature on Cournot's legacy extending the study to his non-mathematical work on economics (Cournot 1863) which has been neglected in most of the 


\section{ecos \\ ECONOMÍ́}

literature. We propose also to go further into the analysis of Walras's and Edgeworth's normative works in order to enrich a comparative analysis of the marginalists' views on imperfect competition.

The rest of the paper is organized as follows: A description of Cournot's pure theory of Monopoly followed by section on his normative views. In the fourth section we consider, first, the influence on Walras's theoretical and political positions on Monopoly and finally we contrast it with the influence of Cournot's views on Edgeworth and Marshall.

\section{Cournot pure theory of competition and monopoly}

For Cournot, perfect competition is a limit case of a general analysis on the determination of prices. Cournot's general theory of competition aims at providing a rationale (to give an explicit rational argument) to the determination of prices in order to go further than the "common sense" notions of the, nowadays named, demand and supply laws. He believes that the propositions like "The price of a commodity is increasing on its demand", are sterile from a scientific point of view1. His alternative proposition consists in providing a representation of the market for a particular good, composed by a given demand function depending on the price (decreasing), with a passive behavior, and a strategic behavior on the supply side of the market. The attention is thus focused on the actions of producers, namely their strategic choices. This reasoning leads him to build the basic framework for what is today known as Industrial Organization and the policy issues derived from it.

Cournot's theory of prices does not aim at providing an explanation of the coordination process of a system of markets. It is not a theory of value based on a general equilibrium model, because there is no such an idea of general coordination of self interested agents. Even if Cournot considers the mutual influence of different goods, and thus different markets, on the determination of the price of each of them (chapter 9 in Cournot 2001), this is only to consider the case of a collusion of complementary inputs contributing to the production of the same good. The main concern of the cournotian approach is whether different degrees of competition affect

\footnotetext{
${ }^{1}$ Cournot (2001: 35-36), chapter 4, paragraph 20.
} 


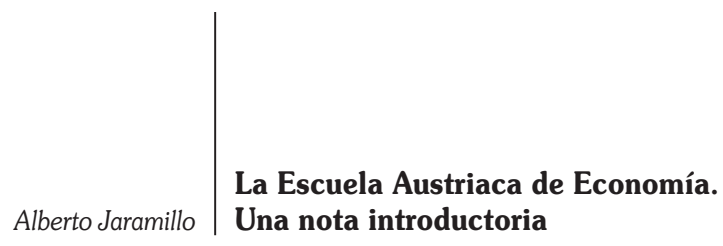

in different ways the final price of a simple good. This constitutes the basis for a solution of multiple applied questions. More precisely, the goal of Cournot's theory of competition is to contribute to the analysis of the distribution of wealth and to provide a rational for the regulation of the market:

... here it is intended to know how, following some changes in production or in commercial relationships, prices will go up, down or will they tend to equilibrate; how gains or losses will be distributed among owners, entrepreneurs, workers ... (Cournot 1863, paragraph 11, p: 19-20)2.

The main achievement of Cournot's theory is the possibility to apply the same principle to different degrees of competition, starting by the pure monopoly case. This implies that perfect competition (i.e. unlimited competition $^{3}$ ) is nor a theoretical, neither a normative, benchmark situation. On the contrary, perfect competition is a particular case $e^{4}$ where each producer or competitor has nil marginal incidences on the price. This situation is attained, not only by the presence of a great number of competitors, but also by the presence of a "threat" for every producer, related to the presence of a perfect substitute for each one of them. The whole theoretical framework is thus constructed upon strategic behavior of agents. A monopolist has to anticipate the variations of the demand for his own good in order to obtain the maximum level of profit (Cournot 2001, chapter 5). When a few number (i.e. two for the simplest case) of competitors is present in the market, the space of strategies (as defined in modern strategic game theoretical analysis) is enlarged to take account not only of the demand but also of others competitors' strategies (Cournot 2001, chapter 7). Finally, when a collusion among producers is possible (Cournot 2001, chapter 9), the strategic behavior is still the defining feature of individuals' behavior. In this case, we cannot talk about a cooperative game solution for the stability of the coalition of producers.

2 Our translation. The original french quotation: «... s'agit-il de savoir comment, par suite de changements dans les conditions de la production ou dans les relations commerciales, les prix hausseront, baisseront, se nivelleront; comment les profits ou les pertes se repartiront entre les propriétaires, les entrepreneurs, les ouvriers ..."

3 In French: Concurrence indéfinie (Chapter 8 in Cournot 2001).

4 See some similar arguments in Dos Santos Ferreira \& Gérard-Varet (2000) and Dos Santos (2002) and (2004). 


\section{ecos

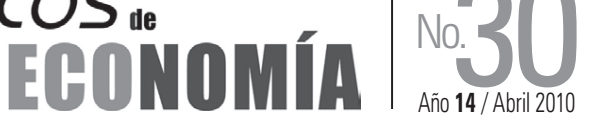

On the contrary, the case proposed by Cournot when the case of collusion among producers is analyzed, is not that of producers of the same good deciding to take advantage of monopoly power, but the formation of a group of producers of different inputs taking part in the production of a unique final good acting together as a monopolist. From this, it follows that each of the participant has interest to take part in the collusion taking into account common information: the demand for the final good. The strategic behavior is not eliminated but reinforced, and the final solution of this situation is an "artificial" monopoly.

The cournotian approach to competition is thus based on the strategic interaction of producers in partial equilibrium analysis. It is important to remark that he solution concept proposed by Cournot does not presuppose the knowledge of the entire set of strategies for every producer (or player). However, the analysis leading to establish a well defined solution for every case is based on reasoning where, by successive approximations, the players discover the relevant set of information about others' strategies. Some authors have underlined the limits of this dynamic analysis, and in particular its lack of coherence because it supposes that during the "try and error" process for one player, an ad-hoc ceteris paribus hypothesis is supposed $^{5}$. This criticism is somehow extreme. The final solution of the problem, given by Cournot, is not false and the suggestion of a dynamic process is a pedagogical device. He is well aware of the problems of stability related to informational issues or possible errors on expectations of the players:

In other terms, this state would not be a stable equilibrium situation; and even being good for both producers, it is not long-standing unless a formal link among them is established. We cannot suppose, in the moral world, men being excepted from error or misleading actions, as it is not possible to find within the physic nature of things a perfect rigid body, a perfectly stable foundation and so on. (Cournot 2001, chapter 7, paragraph 44, p: 62)

5 It has been emphasized by some authors that Cournot's solution to the oligopoly case is an early version of the Nash equilibrium notion (Negishi 2001).

6 Our translation. French original quotation: "En d'autres termes, cet état ne sera pas une situation d'équilibre stable; et, bien que le plus favorable aux deux producteurs, il ne pourra subsister à moins d'un lien formel; parce qu'on ne peut pas plus supposer, dans le monde moral, des hommes exempts d'erreurs et d'inconsidération, que dans la nature physique des corps parfaitement rigides, des appuis parfaitement fixes, et ainsi de suite" 


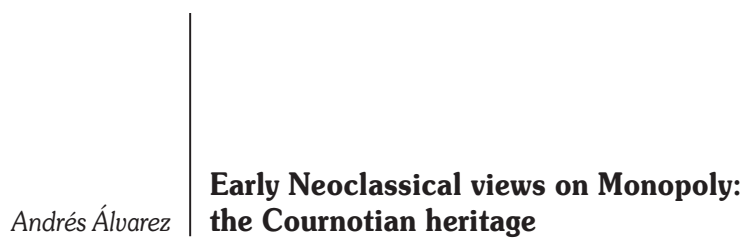

In the case of Monopoly, the same "pedagogical" device is proposed. Cournot supposes that the monopolist producer does not know the actual demand he isfacing. It is gradually discovered by successive approximations, proposing prices producing a reaction on demand and a particular level of income for the monopolist. Given a constant demand function, and its passive character we have underlined so far, the monopolist will finally unveil the actual form of this function and solve the maximization of his own profit function. This is obviously a way to give an empirical sensation of the solution of the monopolist problem, otherwise the hypothesis of perfect information and thus an omniscient agent could be too shocking for the reader. Moreover, as we will show in the next section, Cournot's analysis of the welfare consequence and the regulation policy are based on comparative statics. This therefore requires a solution concept as a benchmark for the analysis and the same solution concept for the final situation. This may seem a methodology similar to nowadays standard Industrial Organization analysis. However, there exists a main difference: in modern normative analysis, economics have adopted a procedure where the "first best" situation of the perfect competition framework constitutes the benchmark for the policy implication analysis. In the cournotian approach, the negative consequences of monopoly are judged from the point of view of political considerations and criteria related to an idea of the "general interest" opposed to the "particular interest". These criteria are established following a very simple normative. This principle is other than what economics uses today: namely the Pareto optimality.

In order to reconstruct the normative criteria proposed by Cournot guiding his policy analysis and in particular the regulation of monopolies one needs to read Cournot's non-mathematical works. In the following section we will expose at a glance his normative analysis based on those almost unnoticed books.

\section{The cournotian normative analysis}

The normative statements in Cournot's work are not very explicit in his best known Recherches sur les principes mathématiques des richesses (Cournot 2001). In order to grasp clearer the policy implications of his analysis we have to explore his non-mathematical book Principes de la théorie des richesses (Cournot 1863). Even if the later has being 


\section{ecos \\ ECONOMÍA ${ }^{N 3} 30$}

considered as a merely transcription into non-mathematic language of the former, Cournot announces in the preface ("au lecteur") of this work the presence of some developments going further his first economic work. Little attention has been paid to these developments.

I have reformulated my 1838 book. I have taken it back by solving some of its problems, developing further some insufficiently developed ideas and fulfilling some points I have avoided to study on it, and in particular I retired the whole algebraic exposition that scared some people on this matters. (Cournot 1863, Au lecteur: II $)^{7}$

Tough, this new work, written in a non-mathematical language, never had the impact Cournot's was searching for. In particular, Cournot's statements on policy matters have been almost completely ignored by modern cournotians and historians of economic thought. In his 1863 book he presents the basic notions of his theory on prices with special emphasis on his main achievement on monopoly price:

$\mathrm{He}$ [the monopolist] could, on the benefit of his monopole, fixe a price of twenty francs per liter for this water: but he will understand very fast, because of the scarcity of the demand, that this price is not the best for him. He will then reduce it successively and then rise it a little if the experience shows him that he has reduced it too much, finally he will stop at a level giving him the highest possible brut revenue. (Cournot 1863, chapter 7: 107) ${ }^{8}$

We can recognize here the pedagogical exposition of the process of discovery, by the monopolist, of the demand function of the market and the well known conclusion: the monopolist fixes the maximum price he can obtain from the market demand. Cournot then presents another general conclusion of his first (mathematical) economic work: the increasing presence of competitors within a market leads to a reduction in the price of the good and an increasing of the level of production. This is

7 Our translation. Original french quotation: «j'ai repris man travail de 1838 en le corrigeant, en le developpant là où les developpements manquaient, en le completant sur les points auxquels je m'étais abstenu de toucher, et surtout en le depouillant absolument de l'attirail d'algebre qui effarouche tant en ces matières".

8 Our translation. Original french quotation: « Il pourrait, à la faveur de son monopole, fixer à vingt francs le prix du litre de cette eau: mais il s'apercevrait bien vite, à la rarete des demandes, que ce prix n'est pas le plus avantageux pour lui: il l'abaissera donc successivement, puis le relèvera un peu si l'expérience lui montre qu'il l'a par trop abaissé et, finalement, il s'arrêtera au taux qui lui donne le plus gros revenue ..." 
a "common sense" argument to argue the desirability of competition and of the establishment of a free market regime. However, in the very last chapters of this same book (1863), Cournot presents a surprising argument against perfect competition and in favor of monopoly, as we shall study.

The notion of competition, in this non-mathematical work, is free from the pure formal considerations of his first book. In fact, in his early book he is restrained to present the competition between producers not as a struggle aiming at obtaining more market-power, namely to attract a greater part of the market demand. This is in fact the origin of the well-known criticism by Bertrand. Following him, the cournotian analysis of competition ignores the fact that an increase in the price asked by a producer leads to a loss of the whole demand and a proportional increase on the demand for his competitor's product. As it is easy to observe, Bertrand's criticism is based on a very different conception of the role of the demand side of the market on the determination of prices. As we stated above, Cournot's pure theory of price (as developed in his 1838 book) is based on the analysis of the active strategic behavior of producers under the assumption of a constant (i.e. passive) market demand. The surprise arrives in his late book, when Cournot develops the following argument on the negative consequences of perfect competition:

If there is in the monopole an element of disagreement between the general and the particular interests, there is also another element of disagreement between the general and the particular interests within competition. Both are equally visible for the common opinion today. When forceful competition leads prices downward, and in particular the price of work, conducing to the malaise of the producers and bringing illness to the productive system, it harms not only those directly affected. This forceful competition becomes harmful for the whole social body, though the apparent advantages for some social classes; as a living organism suffering from one healthy organ stealing nutrients from other organs". (Cournot 1863, book IV, chapter II: 436-437)9.

\footnotetext{
Our translation. Original french quotation: « ... s'il ya dans le monopole un principe de désaccord entre l'intérêt particulier et l'intérêt général, il y en a un autre dans la concurrence, qui ne frappe guère moins aujourd'hui les yeux de la foule. Quand l'aiguillon de la concurrence pousse à avilir les prix, et notamment le prix du travail, jusqu'à amener le malaise des producteurs et à vicier les organes de la production, il ne nuit pas seulement à ceux qui en souffrent immédiatement; il devient nuisible au corps social tout entier, quelque avantage apparent qu'il donne pour le moment à d'autres classes de la société: de même que le corps vivant tout entier souffre de l'embonpoint d'un organe qui dérobe à d'autres organes les sucs nourriciers. »
} 


\section{ecos \\ ECONOMÍA}

Where does this harmful of competitions rest upon? It is related not only with price competition, as it is evident from the above quotation, but also with other strategies used by entrepreneurs to survive and succeed in a competitive market.

If, additionally, competition presses to alter the quality of goods, to seduce consumers with false savings, to produce more than demand can buy, producing continuously commercial crisis, those evils, for the social body as well as for the producers themselves, will be more obvious, so it is also that evident that free competition may create those outcomes (Op. cit., we underline $)^{10}$.

The two arguments presented in this quotation cannot be sustained on the basis of the pure theoretical framework developed in the Recherches sur les principles mathematiques. The first argument is based on the analysis of an integrated system of markets (i.e. general equilibrium analysis): a sector being pulled up by competition pulling down other sectors and producing a systemic crisis. As we have showed so far, Cournot's theory of prices and competition was developed within a partial equilibrium analysis. The second argument is even more striking for it appeals to a theory of competition where the producers are trying to gain part of the market demand against other producers. In particular, trying to "seduce consumers" implies a conception of the demand in contradiction with his assumption on the independence of the demand functions faced by each producer (Cournot 2001, chapter 7, paragraph 43: 59-60). This hypothesis, was exploited by the well-known Bertrand's criticism and well noticed by Edgeworth:

Starting with complete monopoly, we shall find the price continually diminish as the number of monopolists increases, until the point of complete fluidity is reached. This gradual 'extinction' of the influence of monopoly is well traced by Cournot in a discussion masterly, but limited by a particular condition, which may be called uniformity of price, not (it is submitted) abstractedly necessary in cases of imperfect competition. (Edgeworth 1881, p: 47).

10 Our translation. French original quotation: “ (...) Si de plus la concurrence pousse à altérer les qualités, à séduire les consommateurs par l'apparence d'une économie mal entendue, à produire plus que les débouches ne peuvent écouler, ce qui ramène périodiquement des crises commerciales, ses inconvénients, pour le corps social comme pour les producteurs eux mêmes seront encore plus évidents; et pourtant il ne l'est pas moins que la libre concurrence doit amener de tels résultats." 


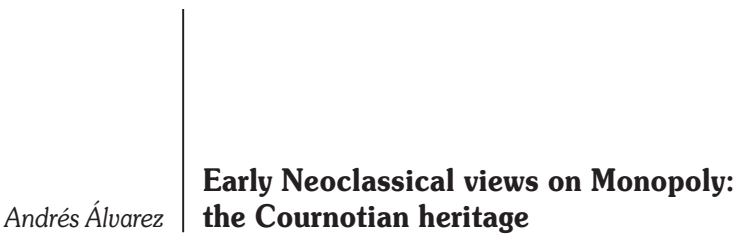

Two interesting conclusions can be derived from these surprising changes on Cournot's arguments. On the one hand, even if his theory of oligopoly was developed under the assumption of "fixed prices", his normative point of view is built upon a different conception of the organization of the markets. Dos Santos Ferreira (2004) resumes clearly Cournot's pure theory of oligopoly:

La notion de concurrence s'insère donc chez Cournot dans un schema non cooperative, où le principe d'uniformité du prix impose cependant une forte coordination ( $\mathrm{p}: 545)$.

Under this pure theoretical conception (i.e. the one developed in his early book) the competitors do not have the power to attract his competitors' demand because there is an automatic adjustment process leading the prices of other competitors to align. As Dos Santos Ferreira (2004) also noticed:

In a certain way, the cournotian producers act in an isolated way as if they were still monopolists, but this is confined within a fraction of the market ( $\mathrm{p}$ : $545)^{11}$.

This automatic mechanism of price alignment is abandoned in his normative analysis about competition. Following this change in his conception of the organization of market, in favor maybe of a more empirical one, Cournot also concludes that the Monopoly could achieve more suitable results because it is a more stable situation. In opposition to the erratic behavior of a competitive market, where producers are guided by their permanent anxiety to gain a part of the total demand against their competitors, the monopolist is never menaced and thus never pushed to act in an irrational manner. These pragmatic considerations are very similar to those we find in Marshall's and Edgeworth's works.

On the other hand, the presence of some elements of ageneral equilibrium framework is the confirmation of an early sliding already present in his first book. In the 11th chapter of this book, Cournot take some risks to go into the perils of a general equilibrium analysis. But he renounces very

11 Our Translation. Original french quotation: «D'une certaine manière, les producteurs cournotiens, agissant chacun de son côté, se comportent encore en monopoleurs, quoique sur une frange du marché ». 


\section{ecos \\ ECONOMÍ́}

fast to continue further. As Dos Santos Ferreira \& Gérard-Varet (2000) recognize it, Cournot tries to avoid the difficulties of general equilibrium, in particular, the necessary modifications on the demand functions. These lead to the introduction of the income and the prices of other commodities as changing arguments of the function and not as parameters like in a partial equilibrium conception. If we return to Cournot's late book (1863) we can find that a great part of the book is developed exploring this kind of considerations. The effect of competition on wages is but one example of this. Cournot analysis the bad consequence of competition on wages and concludes that the organization of workers unions is well justified by the effects of competition (Cournot 1863: book III, chapter X). Moreover, at least two thirds of these books are related to considerations of a very complex framework taking into account the interactions between different sectors of an integrated system of markets.

Most of these conclusions on competition and the normative appreciation of the negative consequences competition and the positives of monopoly have being neglected by the second hand place given to Cournot's late book. We can now advance a conclusion about the role of those different views on Monopoly and competition in Cournot's global work: his pure theoretical conception leads him to conclude on the traditional evaluation on monopoly as an undesirable situation because of the possibility for the monopolists to fix a high price and a low supply. However, a more pragmatic view on monopoly, based on a general equilibrium framework, allows him softening this conclusion and giving a more complex normative point of view. We can now go into the history of the early heritage of Cournot's views to show how this different point of views are to be found in authors like Walras, Edgeworth and Marshall.

\section{The legacy of the two views on competition}

It is necessary to repeat that we do not pretend to assert that the influence of Cournot on the authors we will consider is a direct one. To be sure, even if it is easy and it has been well documented that Cournot's first work on economics was read and well appreciated by those authors, it is not clear whether they were as interested on his 1863 book as they were on the first. Nonetheless, we will try to show that both views on monopoly are associated with those authors and, most important, that the reasons 


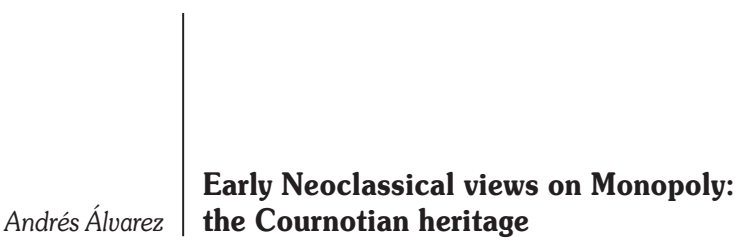

and the theoretical implications of those views are related to those we found in Cournot's works.

\section{Walras: monopoly theory as applied economics and the commutative justice precept}

As it is confirmed by Walras himself, he was influenced by Cournot's reading. But this influence is only recognized on two matters: 1) the methodological position of Cournot's as a champion of the mathematical economics school; 2) the pure theory of monopoly as presented in Cournot's first book.

It is not necessary to go deeper into the importance Walras gave to the mathematical language. as its natural one, for economics. On this point, Walras recognizes the main place of Cournot as the founder father of the school. In particular, he acknowledges the primacy of Cournot's theory of demand. Nonetheless, Walras considers that Cournot's demand function was incomplete for it lacks of the prices of other commodities and the income as arguments of the function. Briefly, Cournot was wrong to try to construct a model within a partial equilibrium framework. Associated with this criticism, Walras accused Cournot to be too much interested on "applied economics" (i.e. empirical questions). This sounds, as far as our considerations are true, very contradictory with the points of views Cournot develops in his last book. In fact, as we have showed, the empirical issues and the normative considerations on competition are analyzed by Cournot within a general equilibrium framework (of course, not completely developed as Walras' one). Here we find the first, contradictory legacy of Cournot analysis on monopoly.

\section{The pure theory of Monopoly as applied economics}

In his "Élements d'Économie Politique Pure", Walras (1988) includes, as his last chapter (41th lesson), some considerations on Monopoly. Given the strict separation between Pure and Applied economics for Walras, this chapter may be considered as an intruder. In fact, we find the same subject as part of his "Études d'Économie Politique Appliquée" (Walras 1992). However, the main difference between those expositions on Monopoly lies on the fact that in the "pure economics" book, Walras develops, what we could name a "pure theory" of Monopoly. This theory, as Walras himself 


\section{ecos \\ ECONOMÍ́ ${ }_{\text {Num }}^{N 3}$}

recognized it, is Cournot's theory with a little contribution of Dupuit's analysis. We can thus argue that Walras's pure theoretical conception of Monopoly is direct legacy of Cournot's. However, two warnings must be given here. First, Walras's notice at the very beginning of his 41th lesson on Monopoly (in his Elements of pure economics) that one main assumption of his entire book has to be abandoned:

... [T] hat of the absolute free competition in exchange, production and capitalization. Thus, so far we know only the effects of free competition. But, whatever the economists say or seems to say, perfect competition is not only possible form of industrial organization" (Walras 1988: 655)12

In fact, following his methodological conception, Walras seems to talk about Monopoly as an "imperfection" of the market. As a "perturbation" of the perfect competition situation. This methodological conception, which has been inherited by the neo-walrasian Arrow-Debreu model, implies that a more realistic case must be understood and judged as a perturbation of a more general, but purely theoretical, situation: the perfect competitive general equilibrium.

However, the reader of the 41th lesson is disappointed because this "imperfection" is not analyzed following the strict method consisting in introducing some modifications of the original "perfect" model. Walras's exposition of the Monopoly theory is developed within a partial equilibrium framework. This is obvious, because it is a direct legacy of Cournot's (2001) chapter 5. However, the epistemological status of this pure theory of Monopoly is reversed in Walras's work. For Walras, this is an applied question, related thus to normative issues.

\section{The normative judgment on Monopoly as matter of justice}

After having presented Cournot's theory of Monopoly in his "Pure Economics" book, Walras go into an important policy issue: the question about the railroads management. Walras's posture on these matters is

\footnotetext{
12 Our translation. Orginal french quotiation : “... celle de la libre concurrence absolue en matière d'échange, de production et de capitalisation. Ainsi, ce que nous connaissons, ce sont les effets de la libre concurrence. Mais quoi qu'en disent, ou qu'en paraissent dire, assez souvent les économistes, la libre concurrence n'est pas le seul mode possible d'organisation de l'industrie..."
} 


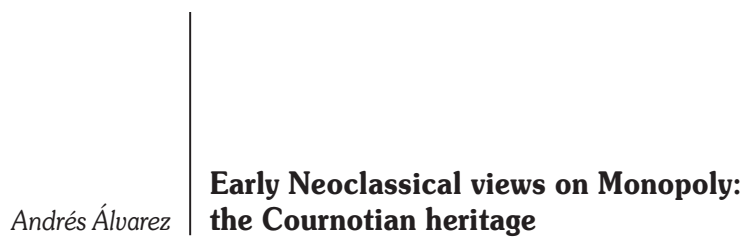

quite surprising: He advocates in favor of the necessity for the Estate to provide this service and against the privatization of it.

The main argument to justify this view on Monopoly is related with a fundamental building block of Walras's whole intellectual program: namely his conception of justice. Following this conception, the general competitive equilibrium situation is a normative benchmark because of his normative properties. Without going further on this questions (see Jaffé 1977), we can use a quotation from the mentioned chapter on Monopoly in Walras's "Applied Economics" book where the violation of perfect competition conditions by monopoly is clearly established. The two main conditions being:

[1] That there exists a unique price for every service and good in the market, this is the price upon which demand and supply equate, [2] and that the selling price equates the production cost of productive services of factors. These two conditions can be reduced to one condition: exchange being made, for all productive services of factors, at exchange rates voluntarily accepted by all factor owners; and this condition is a matter of justice. (Walras 1992: 186, we underline $)^{13}$

This quotation sums up the role of the competitive equilibrium as a norm of justice which constitutes a normative and a theoretical point of reference. A normative one because Walras always judges the "imperfect competition situations" as deviations from the "first best" situation of perfect competition. But also a theoretical reference, because in order to understand, from an analytical point of view, a particular organization of the market, the walrasian analysis describes it as a departure from the this theoretical referent. It is thus also a methodology for pure economics and not only a normative analysis (see Benetti 1997).

To grasp the implication of this methodological point of view for Walras's conception of Monopoly and his political position in favor of the intervention of the Estate on the railroad industry, we have to explain how

13 Our translation. Original French quotation: «Qu'il n'y ait, pour les services et pour les produits, qu'un seul prix sur le marché, celui auquel a lieu l'égalité de l'offre et de la demande, et que le prix de vente des produits soit égal à leur prix de revient en services, ces deux conditions n'en font qu'une seule et unique qui est que les services s'échangent les un contre les autres suivant des proportions communes résultant des dispositions de tous leurs propriétaires; et cette condition est une condition de justice ... » 


\section{ecos

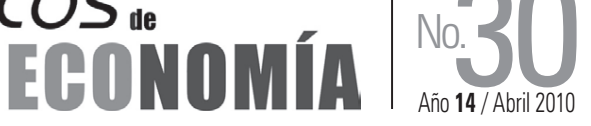

Walras's judge the Monopoly as a transgression of the two main features of the perfect competitive situation. This will allow us to understand how Walras's normative analysis on Monopoly leads him to propose a modification on the theoretical conception of Cournot's pure theory.

On the one hand, the Monopoly goes against the equality between costs (i.e. prix de revient) and total income for the entrepreneur (i.e. prix de vente). The explanation of this is given by the strict application of Cournot's pure theory of Monopoly: a monopolist can sell at high price because of his market power. On the other hand, and here comes the theoretical departure from the cournotian framework, the monopolist is always capable to discriminate prices for each consumer. Here, Walras follows Dupuit's theory against the assumption of the unique price postulated by Cournot. Walras gives us a quotation by Dupuit:

This solution, says Dupuit, stands upon this general principle: what the price of a service must be is not what it costs for the provider of this service, but the amount of the valuation made by the receiver of the service following the importance he gives to it. We cannot accept without restriction this so-called principle, that being formulated in that absolutist form would be harmful against every form of Justice. (Walras 1992, p: 192)14

We now come to the core of the normative problem. It is because the railroad is a natural monopoly, that it cannot be given to the private capital to exploit it: because of an argument of justice. Thus, it belongs to the Estate, the community as a whole, to take control of the railroads to avoid the injustices of private monopolist. In fact, a private monopolist will charge a differentiated price scheme. On the contrary, the Estate will charge only the cost of production (i.e. prix de revient). We will show it in the next section that there is an important difference between Walras and Edgeworth - Marshall, concerning this particular point of view.

Summing up, Walras has a normative position against the existence of private monopolies. This is supported on a theoretical conception of it that departures from the Cournotian pure theory following Dupuit's theory of

14 Our translation. Original french quotation: "“'Cette solution, dit Dupuit, repose sur ce principe général, c'est qu'il faut demander pour prix du service rendu non pas ce qu'il coûte à celui qui le rend, mais une somme en rapport avec l'importance qu'y attaché celui à qui il est rendu. Nous ne saurions, quant à nous, accepter sans restrictions ce soi-disant principe qui, énoncé d'une façon aussi absolue, serait destructive de toute justice. » 


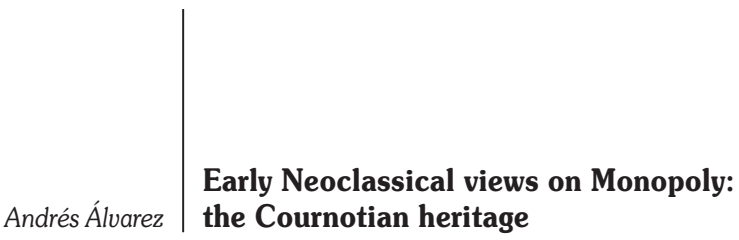

differentiation price policy of monopolists. Even if Cournot's normative analysis on monopolies is built upon a general equilibrium framework, we showed that Walras takes the opposite way around: the theoretical framework within which he tackles the case of monopoly is the partial equilibrium analysis of a mixture of Cournot and Dupuit theories.

\section{Edgeworth and Marshall: some normative coincidence in a different theoretical framework}

Edgeworth and Marshall highly praised Cournot. In particular they recognized his originality and audacity putting economics into a mathematical language. However, both departed from Cournot analysis of the oligopoly model, introducing this analysis in a different conception of the notion of competition. Concerning Cournot's monopoly theory, both Marshall and Edgeworth, agree on its basic conclusions, but they saw this model as the most primitive theory of Monopoly. The both tried to enriched, not to abandon, the cournotionan framework. Nevertheless, this theoretical enrichment leads them to throw away the main theoretical hypothesis of Cournot's pure theory of Monopoly.

Edgeworth (2003), following Marshall (Marshall 1890, book V, Chapter 13), states that Cournot's theory of the price of monopoly is only a particular case of a more general model. The general case, according to Edgeworth, is not to suppose that the monopolist is constantly threatened by competitors. This conception of the monopoly derives from their general views on competition. In fact, the well-known notion of recontracting (Edgeworth 1881) supposes the existence of a permanent menace point for every competitor. The whole theory of prices in Edgeworth, is built upon the assumption of the constant possibility to break contracts and recontract with other agents. In this sense, the edgeworthian market is view as a huge zone where information flaws are essential. In this framework, Edgeworth proposes the following idea: if a monopolist is trying to keep his market power, he cannot ask for the maximum price an agent would pay, but an intermediary price between his own marginal cost of production and this maximum level. Here we rejoin the Marshallian influence on Edgeworth. Marshall has presented a concept for this situation which he called (Marshall 1890, Ibid) the Compromised Benefit. Both English authors considered 


\section{ecos \\ ECONOMÍ́ ${ }_{\text {Nunguma }}^{N 30}$}

that the general case is this constantly threaten monopolist. The case where the monopoly can put the highest price is what Edgeworth presents as nonsense:

That is, excepting the arbitrary supposition that the second monopolist is such a fool as to act in the manner ascribed to him by Cournot's equation. But even if he were to do so, though there would exist a definite position of equilibrium, it would not be the one assigned by the theory here combated." (Edgeworth 1925, p: 138).

Edgeworth transposed the analysis of monopoly into a quasi-competitive framework. Being more precise, Edgeworth's analysis consists on the case of a monopolist which is potentially confronted to the presence of some competitors: this means an oligopoly case. In fact Egeworth's general price theory is a generalization of an oligopoly case where: 1 ) the pure monopolist of Cournot can only exist if and only if he has the whole monopoly of the market, namely he has a "natural monopoly" in Edgeworth's conception; 2 ) the perfect competitive situation is attained when a important number of competitors go into the market and the information about contracts is public.

Upon this theoretical framework, Edgeworth nourishes a normative appreciation on monopoly very close to Marshall's and Cournot's. In fact, the three authors under consideration, have some arguments in favor of the existence of private monopolies. This contrasts with Walras's radical opposition. The arguments are also very different from those that Walras could accept.

Edgeworth clearly sums up his normative position:

"In general, prices under monopoly are higher than they would have been under competition, other things being equal. But other things are not equal, for the expenses of production are apt to be less under monopoly, owing (1) to the advantages of production on a large scale; (2) the avoidance of waste in advertising against each other some 3.000.000 dollars, of which two-thirds at least could be saved by combination." (Edgeworth 2003, p: 487).

These empirical arguments in favor of the monopolists have a similar status as those by Cournot, presented above. However, two important differences are present here: the presence of increasing returns to scale 


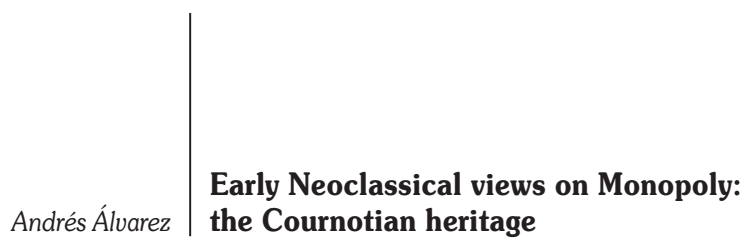

and the costs of advertising. However, this last point is not too far from the cournotian idea that monopolists do not have be worry about competitors. Marshall in the third book of his "Industry and trade" (Marshall 1919).

Edgeworth's partial defense of monopoly is supported on his general price theory, however, Cournot has to go further, or even to abandon his price theory and rely on purely empirical appreciations. In fact, the case of increasing returns and, even clearer, the save on advertising expenses is perfectly conceivable as a case within Edgeworth's analysis, because the presence of the threatening competitors. Nonetheless, a general equilibrium approach à la Cournot, could possible get rid of those situations. It is finally clear that those cases cannot fit into any consideration of walrasian pure price theory for the absence of strategic behaviors is the main characteristic of it.

\section{Concluding remarks}

Besides their theoretical works Marginalists authors show a keen interest in the practical issues of their times. In particular, the regulation of non-competitive structures were since the end of the $19^{\text {th }}$ century a main issue for economists. Their approach these issues supported on their theoretical framework allowing them to identify the appropriate spaces for government intervention; those where perfect competition doesn't hold. The action of the State is justified not only in the presence of market failures but also because it is the only way to address justice issues, which lay beyond the scope of pure theory.

This exploration also shows how authors as Walras, tough considered a pure theoretician, believe there is no single recipe for dealing with different market structures. Monopolies should be regulated differently depending on the goods and services they provide.

Finally, Marginalists considered that problems of political economy cannot be reduced to compatibility of incentives or mechanism design: we must consider other motivations of human action and the political institutions in order to have a complete picture and optimal solutions. 


\section{ecos \\ ECONOMÍ́}

\section{References}

Benetti, C. (1997), "El método normativo de la teoría económica positiva", Cuadernos de Economía, 16:26, pp. 7-19.

Cournot, A-A. (2001), Recherches sur les príncipes mathématiques de la théorie des richesses, Dunod, Paris. Originally published in 1838 by Hachette, Paris.

Cournot, A-A. (1863), Principes de la théorie des richesses, Paris, Hachette.

Dos Santos Ferreira, R. \& Gérard-Varet, L-A. (2000), "Introduction", Cahiers d'Économie Politique, No. 7, Qu'a-t-on appris sur la concurrence imparfaite depuis Cournot ?: pp. 7-30.

Dos Santos Ferreira, R (2002), "Cournot Antoine-Augustin: Recherches sur les principles mathématiques de la théorie des richesses", in Dictionnaire des grands oeuvres économiques, directed by Greffe, X., Lallement, J. \& De Vroey, M. Dalloz, Paris, pp. 104-114.

Dos Santos Ferreira, R (2004), "Guerre et paix : variations sur la notion de concurrence au siècle de Cournot", Revue économique, 55:3, pp. 543556.

Edgeworth, F. Y. (1881). Mathematical Psychics, London, C. Kegan Paul.

Edgeworth, F. Y. (1925), "The Pure Theory of Monopoly", in F.Y. Edgeworth, Papers Relating to Political Economy, MacMillan, Volume 1: pp. 111-142.

Edgeworth, F. Y. (2003), "Monopoly", En: Selected Articles in Palgrave's Dictionary of Political Economy, in Newman (ed.) 2003.

Friedman, J. (2000), "The legacy of Augustin Cournot", Cahiers d'Économie Politique, 37: pp. 31-46.

Jaffé, W. (1977), "The normative bias of the Walrasian Model: Walras vs. Gossen", Quarterly Journal of Economics, 91:3, pp. 371-387. 


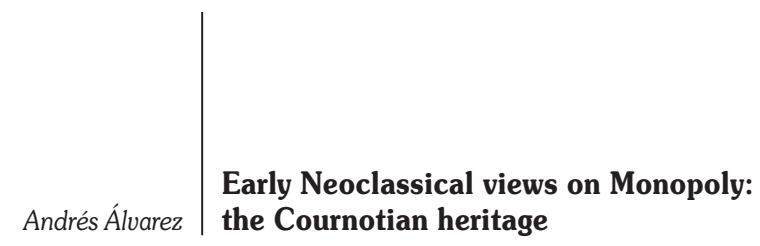

Marshall, A. (1890), Principles of economics, London: MacMillan and co.

Marshall, A. (1919) Industry and trade, London: MacMillan and co.

Negishi, T. (2001), "Introduction" in Cournot (2001), p: VII-XXXII.

Newman, P. (ed.) (2003), F. Y. Edgeworth's Mathematical Psychics and Further Papers on Political Economy, Oxford University press.

Walras, L. (1988). Eléments d'économie politique pure ou théorie de la richesse sociale. Auguste et Léon Walras GEuvres économiques complètes. Volumen VIII. Paris: Économica.

Walras, L. (1992) [1898]. « Monopoles : L'État et les Chemins de Fer ». In Etudes d'économie politique appliquées (Théorie de la production de la richesse sociale). Auguste et Léon Walras GEuvres économiques complètes. Volumen X: 181-218. Paris: Economica. 